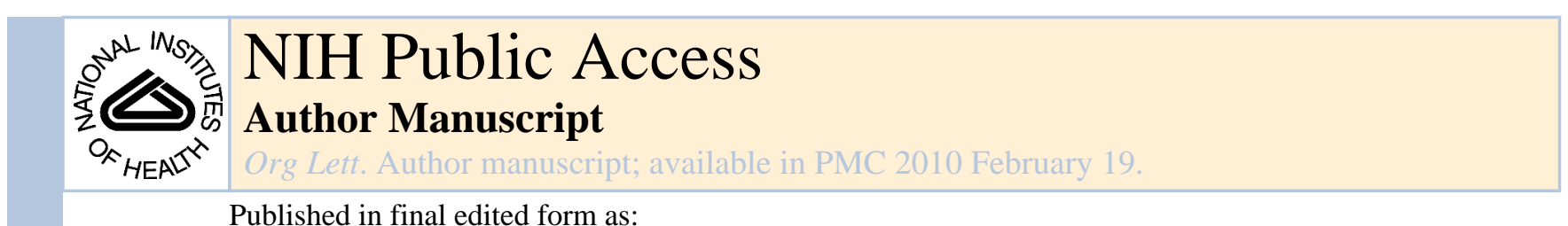

Published in final edited form as:

Org Lett. 2009 February 19; 11(4): 831-834. doi:10.1021/ol802829n.

\title{
Total Synthesis of Apoptolidin A
}

\author{
Michael T. Crimmins, Hamish S. Christie, Alan Long, and Kleem Chaudhary \\ Venable and Kenan Laboratories of Chemistry, Department of Chemistry, University of North \\ Carolina at Chapel Hill, Chapel Hill, NC 27599-3290
}

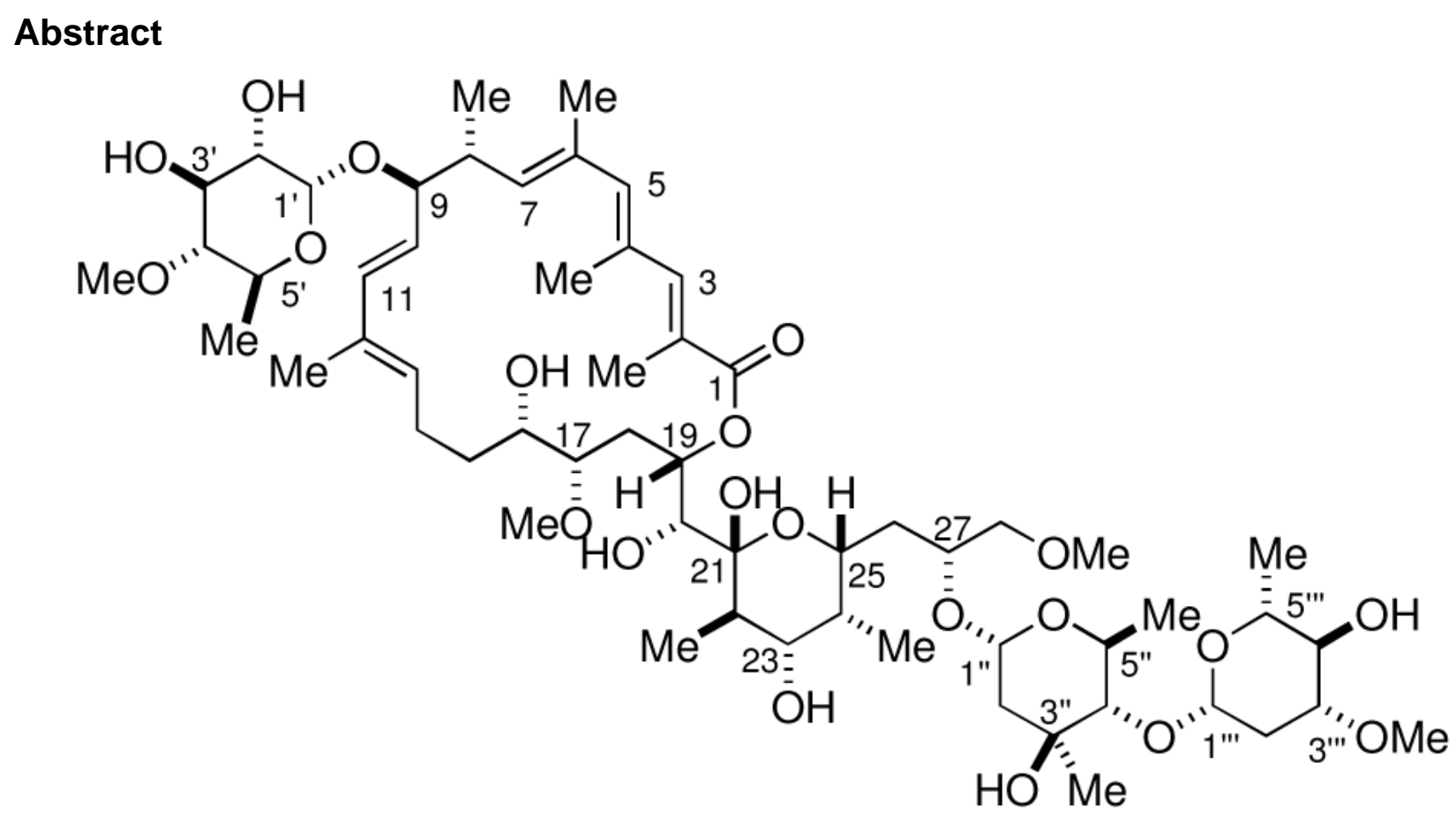

Apoptolidin A 1

A highly convergent, enantioselective total synthesis of the potent antitumor agent apoptolidin A, has been completed. The key transformations include highly selective glycosylations to attach the $\mathrm{C} 27$ disaccharide and the C9 6'-deoxy-- -glucose, a cross metathesis to incorporate the C1-C10 trienoate unit, and a Yamaguchi macrolactonization to complete the macrocycle. Twelve stereocenters in the polypropionate segments and sugar units were established through diastereoselective chlorotitanium enolate aldol reactions.

Apoptolidins A-D (Figure 1) are secondary metabolites of Nocardiopsis sp. which are potent, selective inducers of programmed cell death in rat glia cells transformed with the adenovirus E1A oncogene. Apoptolidin A was isolated by Hayakawa in 1997, and its structure was elucidated by a combination of NMR spectroscopy and molecular model techniques. ${ }^{1}$ The minor metabolites apoptolidins $\mathrm{B}, \mathrm{C}$, and $\mathrm{D}$ were recently isolated and identified by Wender. 2,3 Importantly, apoptolidin A has no effect on normal cells at concentrations as high as 88 $\mu \mathrm{M}$, while the E1A transformed glial cells undergo apoptotic cell death when exposed to 
apoptolidin A at concentrations of $10 \mathrm{nM} .{ }^{1}$ This selective activity of cancer therapeutics is a major factor in minimizing side effects of chemotherapeutic agents.

The apoptolidins have been the subject of intense synthetic and biological ${ }^{4}$ investigations because of their potential as agents for the treatment of cancer. ${ }^{5}$ Two total syntheses of apoptolidin $A,{ }^{6}$ several syntheses of the aglycone, known as apoptolidinone, ${ }^{7}$ including one from our laboratory, ${ }^{8}$ a number of partial syntheses, ${ }^{9}$ as well as selective synthetic modifications ${ }^{10}$ have been reported.

Apoptolidin A (1, Scheme 1) is comprised of a macrocyclic lactone and two unusual carbohydrate units attached through glycosidic linkages at the $\mathrm{C} 9$ and $\mathrm{C} 27$ hydroxyl groups. Our highly convergent approach to the synthesis of apoptolidin A focused initially on the individual preparation of the aglycone, apoptolidinone, ${ }^{8}$ and the carbohydrate units, $9 \mathrm{e}$ with the expectation that the approach to apoptolidinone could be adapted to a synthesis of apoptolidin A by a late-stage attachment of the sugar units to advanced intermediates in the apoptolidinone synthesis.

The glycosyl fluoride $\mathbf{4}$ derived from L-olivomycose and D-oleandrose would be utilized to attach the required disaccharide at C27 of mixed ketal 2 or a similar advanced intermediate prior to incorporation of the trienoate $\mathbf{3}$. Sulfoxide $\mathbf{5}$ would serve as the glycosylating agent for the incorporation of the 6'-deoxy-L-glucose unit at C9 either immediately before or after assembly of the C1-C10 and C10-C28 subunits via a stereoselective olefin cross-metathesis reaction. Mixed ketal $\mathbf{2}$ and trienoate $\mathbf{3}$ were advanced intermediates in our recently reported synthesis of apoptolidinone. ${ }^{8}$

The required glycosyl donors $\mathbf{4}$ and $\mathbf{5}$ for the incorporation of the sugar units were obtained as illustrated in Schemes 2 and 3. Each of the individual monosaccharide units were obtained by de novo synthesis through the application of a chlorotitanium glycolate aldol approach to establish the $\mathrm{C} 4$ and $\mathrm{C} 5$ stereocenters of each of the monosaccharides. $9 \mathrm{e}$

The necessary glycosyl fluoride $\mathbf{4}$ was accessed from the protected disaccharide $\mathbf{1 0}$ as shown in Scheme 2. Direct exposure of the hemiacetal 10 to DAST provided the glycosyl fluoride 4 $(>10: 1 \alpha: \beta){ }^{6 c}$ Since the glycosyl fluoride was somewhat unstable, it was utilized in the subsequent glycosylation of the $\mathrm{C} 27$ hydroxyl group without further purification.

The synthesis of 6'-deoxy-L-glucose (the C9 sugar unit) donor 5 was readily accomplished from lactone $6^{9 \mathrm{e}}$ (Scheme 3). Protection of the diol as the corresponding TBS ether 7 was followed by reduction of the lactone with $i$ - $\mathrm{Bu}_{2} \mathrm{AlH}$ to deliver the protected 6 -deoxy-L-glucose 8. The hemiacetal 8 was converted to mixed acetal $9\left((5: 1 \alpha: \beta)\right.$ by exposure to $\mathrm{PhSSiMe}_{3}$ in the presence of $\mathrm{ZnI}_{2}$. The required glycosyl donor $\mathbf{5}$ was obtained as a 2.5:1 mixture of isomers in $72 \%$ yield by oxidation of the thioacetal with $m$-CPBA. $6 \mathrm{c}$

The asssembly of the four key subunits for the completion of the synthesis of apoptolidin A began with the modification of mixed ketal $\mathbf{2}$. Mixed ketal $\mathbf{2}$ was an advanced intermediate from the recently completed synthesis of apoptolidinone, and was available in multigram quantities through 17 synthetic steps involving an interative aldol sequence. ${ }^{8}$

The key C11-C28 diene $\mathbf{1 2}$ was accessible by either of two sequences from hemiketal $\mathbf{2}$ as illustrated in Scheme 4. Attachment of the C27 disaccharide could be accomplished in high yield (74\%) with excellent stereoselectivity $(7: 1, \alpha: \beta)$ by treatment of $\mathrm{C} 27$ alcohol 2 with stannous chloride in the presence of glycosyl fluoride 4 . The $\mathrm{C} 13$ acetate was selectively cleaved in the presence of the C19,20 carbonate whereupon the resultant primary alcohol was oxidized under Swern ${ }^{11}$ conditions to produce aldehyde $\mathbf{1 1}$ in $89 \%$ yield. Two sequential Wittig olefinations completed the synthesis of diene 12 in $80 \%$ overall yield. Alternately, the 
diene unit could be incorporated prior to the attachment of the $\mathrm{C} 27$ discaccharide. The $\mathrm{C} 27$ alcohol 2 was protected as its triethylsilyl ether followed by removal of the C13 acetate and subsequent oxidation of the alcohol to the aldehyde 13. Stabilized Wittig olefination of the aldehyde in chlorobenzene at $90{ }^{\circ} \mathrm{C}$ was accompanied by cleavage of the C27 TES ether. Methylenation of the unsaturated aldehyde provided the desired diene alcohol 14.

Stereoselective glycosylation of the C27 alcohol $\mathbf{1 4}$ as described previously for alcohol 2 delivered diene 12 in excellent yield.

Completion of the synthesis of apoptolidin A is illustrated in Scheme 5. Exposure of the alkenes $3^{8}$ and 12 to the Grubbs heterocyclic carbene catalyst $\left[\mathrm{Cl}_{2}\left(\mathrm{Cy}_{3} \mathrm{P}\right)(\mathrm{IMes}) \mathrm{Ru}=\mathrm{CHPh}\right]^{12}$ provided the desired $E$ isomer 15 through a critical complex cross-metathesis 8,13 in good yield ( $>95: 5$ $E: Z$ by ${ }^{1} \mathrm{H}$ NMR analysis). An attempted cross metathesis reaction failed when the reaction was performed after the glycosidation of the $\mathrm{C} 9$ oxygen. To complete the synthesis of apoptolidin $\mathrm{A}$, attachment of the sugar unit at $\mathrm{C} 9$ and macrolactonization were required. $\mathrm{A}$ mixture of alcohol $\mathbf{1 5}$ anhydride and sulfoxide $\mathbf{5}$ was exposure to triflic stereoselectively providing the glycoside $\mathbf{1 6}$. Treatment of the ester $\mathbf{1 6}$ with $\mathrm{LiOH}$ at room temperature rapidly cleaved the carbonate group and eventually the ester, to give a good yield of the desired seco acid. Regioselective macrolactonization at C19 proceeded smoothly under Yamaguchi's conditions to deliver the macrolactone. ${ }^{14}$ Finally, cleavage of the silyl ethers and hydrolysis of the mixed methyl acetal were effected in one operation using $\mathrm{H}_{2} \mathrm{SiF}_{6}$ to furnish apoptolidinon A (1). Synthetic apoptolidin A was identical to an authentic sample.

The successful total synthesis utilized diastereoselective chlorotitanium aldol reactions to establish twelve (carbons $4^{\prime}, 5^{\prime} ; 4^{\prime \prime}, 5^{\prime \prime} ; 4^{\prime \prime \prime}, 5^{\prime \prime \prime}, 8,9 ; 22,23$; and 24, 25) of the 24 stereocenters of apoptolidin A and exploited a complex cross metathesis to assemble the two major fragments and construct the $\mathrm{C} 10-\mathrm{C} 13$ diene unit.

\section{Supplementary Material}

Refer to Web version on PubMed Central for supplementary material.

\section{Acknowledgment}

Financial support from the National Cancer Institute (CA63572) is gratefully acknowledged. We thank Professor Paul A. Wender and Dr. Kate Longcore, Stanford University, for generously supplying an authentic sample of apoptolidin A.

\section{References}

1. (a) Kim JW, Adachi H, Shin-ya K, Hayakawa Y, Seto H. J. Antibiot 1997;50:628. [PubMed: 9711255]

(b) Hayakawa Y, Kim JW, Adachi H, Shin-ya K, Fujita K, Seto H. J. Am. Chem. Soc 1998;120:3524.

2. Wender PA, Sukopp M, Longcore K. Org. Lett 2005;7:3025. [PubMed: 15987196]

3. Wender PA, Longcore K. Org. Lett 2007;9:691. [PubMed: 17286376]

4. (a) Salomon AR, Voehringer DW, Herzenberg LA, Khosla C. Chem. and Biol 2001;8:71. [PubMed: 11182320] (b) Salomon AR, Zhang YB, Seto H, Khosla C. Org. Lett 2001;3:57. [PubMed: 11429871] (c) Salomon AR, Voehringer DW, Herzenberg LA, Khosla C. Proc. Nat. Acad. Sci 2000;97:14766. [PubMed: 11121076]

5. Daniel PT, Koert U, Schuppan J. Angew. Chem Int. Ed 2006;45:872.

6. (a) Wehlan H, Dauber M, Fernaud MTM, Schuppan J, Mahrwald R, Ziemer B, Garcia MEJ, Koert U. Angew. Chem., Int. Ed 2004;43:4597. (b) Wehlan H, Dauber M, Fernaud MTM, Schuppan J, Kieper S, Mahrwald R, Garcia MEJ, Koert U. Chem. Eur. J 2006;12:7378. (c) Nicolaou KC, Fylaktakidou KC, Monenschein H, Li YW, Weyershausen B, Mitchell HJ, Wei HX, Guntupalli P, Hepworth D, Sugita K. J. Am. Chem. Soc 2003;125:15433. [PubMed: 14664589] (d) Nicolaou KC, Li YW, Sugita K, Monenschein H, Guntupalli P, Mitchell HJ, Fylaktakidou KC, Vourloumis D, Giannakakou P, 
O’Brate A. J. Am. Chem. Soc 2003;125:15443. [PubMed: 14664590] (e) Nicolaou KC, Li Y, Fylaktakidou KC, Mitchell HJ, Sugita K. Angew. Chem., Int. Ed 2001;40:3854. (f) Nicolaou KC, Li Y, Fylaktakidou KC, Mitchell HJ, Wei HX, Weyershausen B. Angew. Chem., Int. Ed 2001;40:3849.

7. (a) Schuppan J, Wehlan H, Keiper S, Koert U. Angew. Chem., Int. Ed 2001;40:2063. (b) Wu B, Liu QS, Sulikowski GA. Angew. Chem., Int. Ed 2004;43:6673. (c) Schuppan J, Wehlan H, Keiper S, Koert U. Chem. Eur. J 2006;12:7364. (d) Ghidu VP, Wang JQ, Wu B, liu QS, Jacobs A, Marnett LJ, Sulikowski GA. J. Org. Chem 2008;73:4949. [PubMed: 18543990]

8. Crimmins MT, Christie HS, Chaudhary K, Long A. J. Am. Chem. Soc 2005;127:13810. [PubMed: 16201800]

9. (a) Abe K, Kato K, Arai T, Rahim MA, Sultana I, Matsumura S, Toshima K. Tetrahedron Lett 2004;45:8849. (b) Bouchez LC, Vogel P. Chem. Eur. J 2005;11:4609. (c) Chang SS, Xu J, Loh TP. Tetrahedron Lett 2003;44:4997. (d) Craita C, Didier C, Vogel P. J. Chem. Soc., Chem. Commun 2007:2411. (e) Crimmins MT, Long A. Org. Lett 2005;7:4157. [PubMed: 16146376] (f) Daniel PT, Koert U, Schuppan J. Angew. Chem., Int. Ed 2006;45:872. (g) Jin BH, Liu QS, Sulikowski GA. Tetrahedron 2005;61:401. (h) Nicolaou KC, Li YW, Weyershausen B, Wei HX. J. Chem. Soc., Chem. Commun 2000:307. (i) Paquette WD, Taylor RE. Org. Lett 2004;6:103. [PubMed: 14703361] (j)

Schuppan J, Ziemer B, Koert U. Tetrahedron Lett 2000;41:621. (k) Sulikowski GA, Lee WM, Jin B, Wu B. Org. Lett 2000;2:1439. [PubMed: 10814467] (1) Toshima K, Arita T, Kato K, Tanaka D, Matsumura S. Tetrahedron Lett 2001;42:8873. (m) Handa M, Scheidt KA, Bossart M, Zheng N, Roush WRJ. Org. Chem 2008;73:1031. (n) Handa M, Smith III, W J, Roush WR. J. Org. Chem 2008;73:1036. [PubMed: 18163646]

10. (a) Wender PA, Jankowski OD, Tabet EA, Seto H. Org. Lett 2003;5:2299. [PubMed: 12816433] (b) Wender PA, Jankowski OD, Tabet EA, Seto H. Org. Lett 2003;5:487. [PubMed: 12583750] (c) Wender PA, Gulledge AV, Jankowski OD, Seto H. Org. Lett 2002;4:3819. [PubMed: 12599467]

11. Swern D, Mancuso AJ, Huang S. J. Org. Chem 1978;43:2480.

12. Scholl M, Ding S, Lee CW, Grubbs RH. Org. Lett 1999;1:953. [PubMed: 10823227]

13. Chatterjee AK, Choi TL, Sanders DP, Grubbs RH. J. Am. Chem. Soc 2003;125:11360. [PubMed: 16220959]

14. Inanaga J, Hirata K, Saeki H, Katsuki T, Yamaguchi M. Bull. Chem. Soc. Jpn 1979;52:1989. 


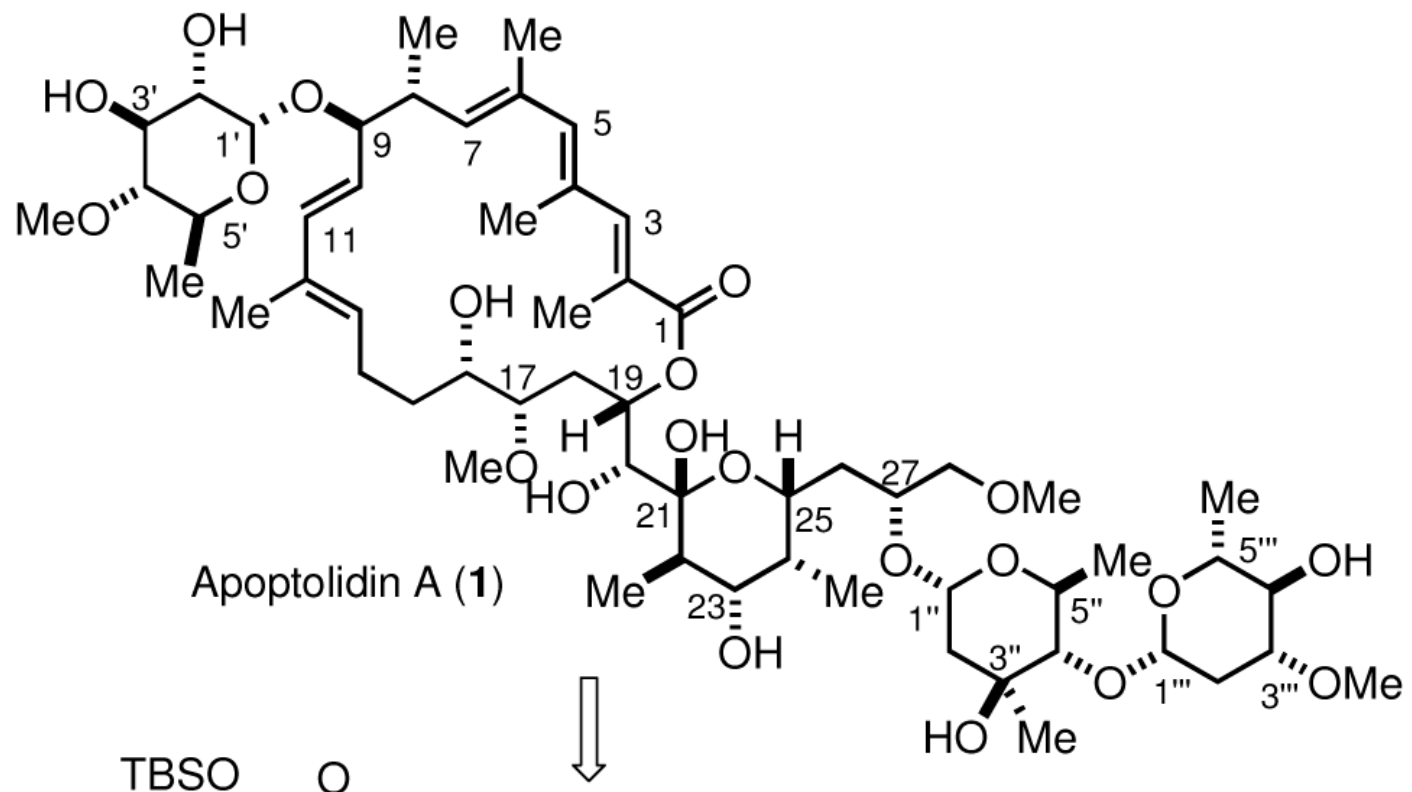

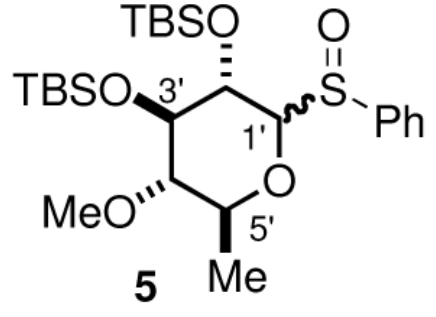<smiles>C=CC(C)=CC(C)=CC(C)=CC(C)=CC(C)=CC(=O)C(=O)OCC</smiles><smiles>CCOCCO[SbH3]</smiles>

2
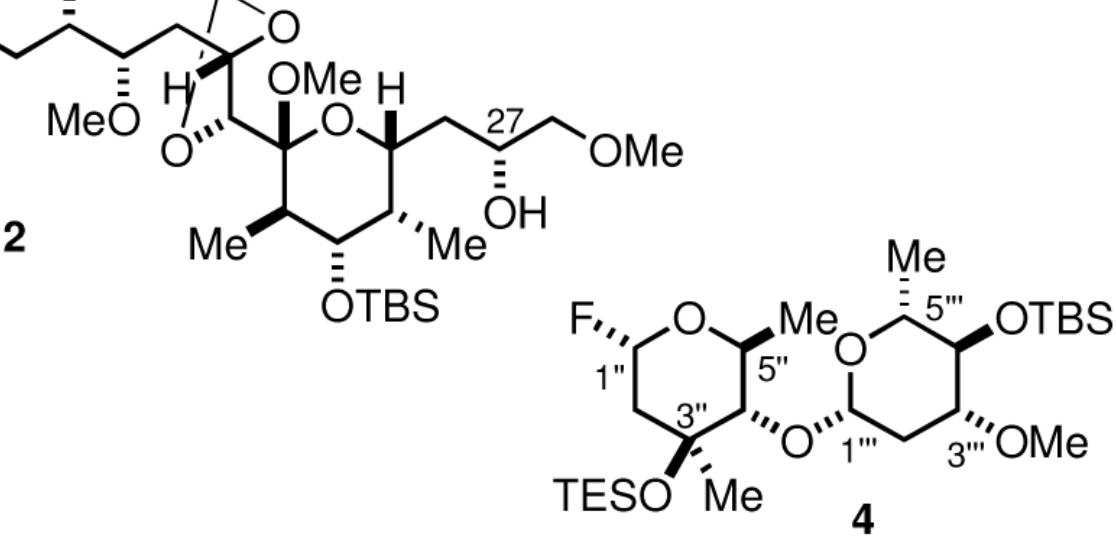

Scheme 1. Retrosynthesis for Apoptolidin A 


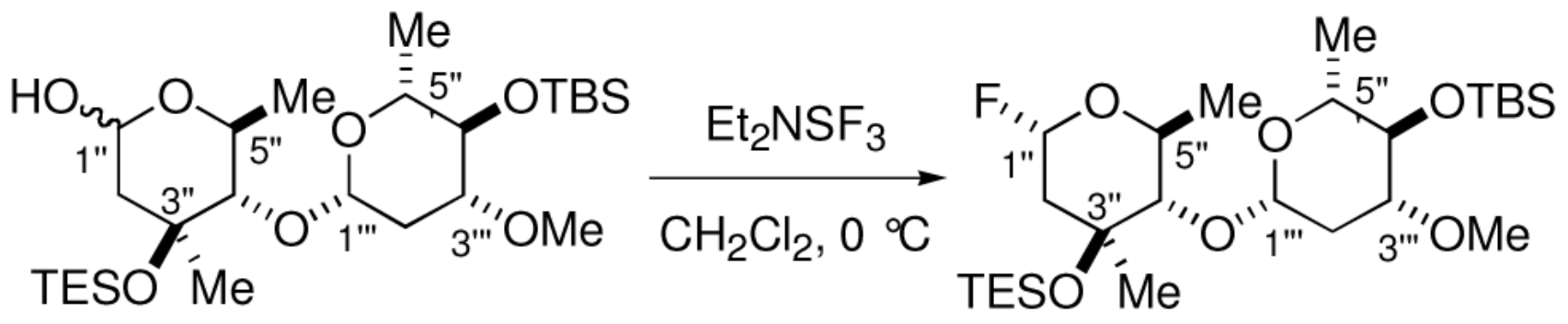

Scheme 2. Synthesis of the C27 Disaccharide 
<smiles>CO[C@@H]1[C@H](C)OC(=O)[C@H](O)[C@@H]1O</smiles>

6<smiles>CO[C@H]1C(C)O[C@@H](O)[C@@H]([OH+])[C@@H]1O[SbH3]</smiles>

8
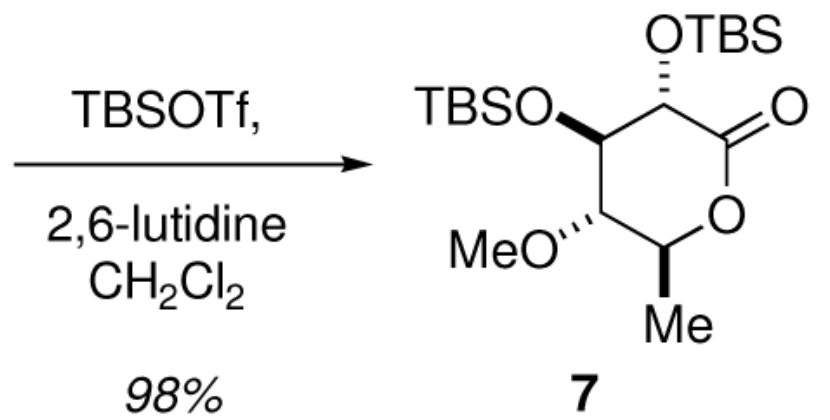
$i-\mathrm{Bu}_{2} \mathrm{AlH}$
$\mathrm{CH}_{2} \mathrm{Cl}_{2}$ $88 \%$

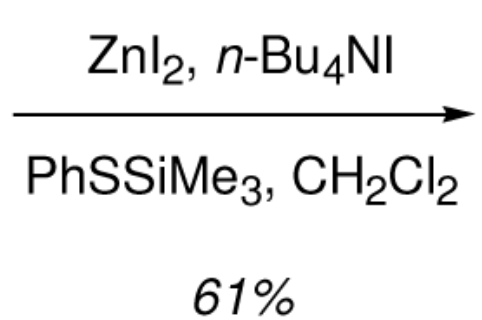

$m-\mathrm{CPBA}, \mathrm{CH}_{2} \mathrm{Cl}_{2}$ $-78 \%$ C, $72 \%$

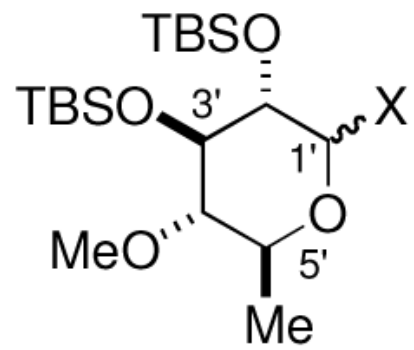

Scheme 3. Synthesis of the C9 Sugar Unit 


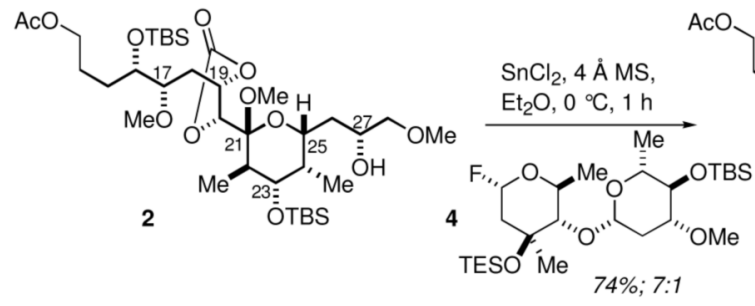

$74 \% ; 7: 1$

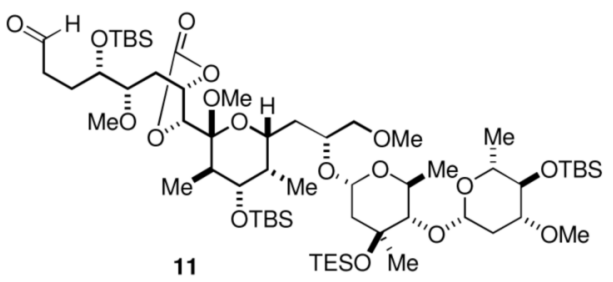

11

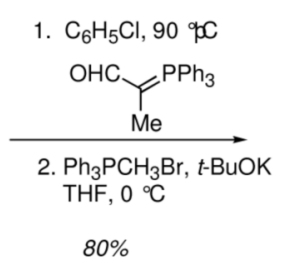

$80 \%$
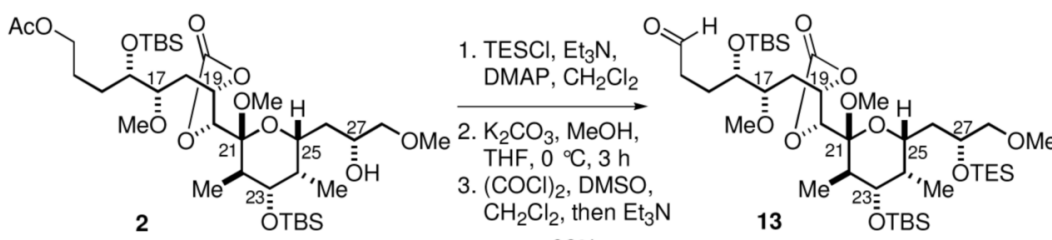

1. $\mathrm{C}_{6} \mathrm{H}_{5} \mathrm{Cl}, 90{ }^{\circ} \mathrm{C}$

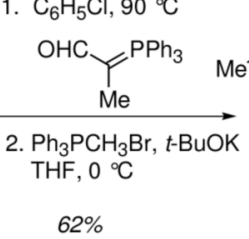

$62 \%$

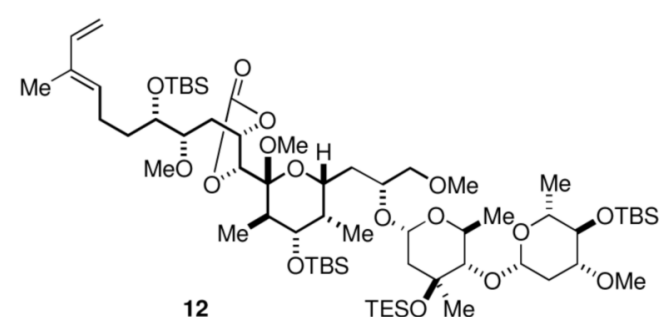

12

1. $\mathrm{K}_{2} \mathrm{CO}_{3}, \mathrm{MeOH}$, THF, $0{ }^{\circ} \mathrm{C}, 3 \mathrm{~h}$

2. $(\mathrm{COCl})_{2}$, DMSO, $\mathrm{CH}_{2} \mathrm{Cl}_{2}$,

$89 \%$

$\mathrm{SnCl}_{2}, 4 \AA \mathrm{AS}$

$\mathrm{Et}_{2} \mathrm{O}, 0{ }^{\circ} \mathrm{C}, 1 \mathrm{~h}$

glycosyl fluoride 4

$81 \%$ brsm; $7: 1$

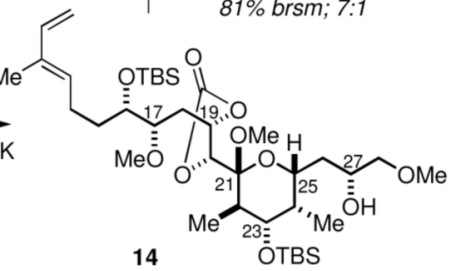

Scheme 4. Attachment of the C27 Disaccharide 

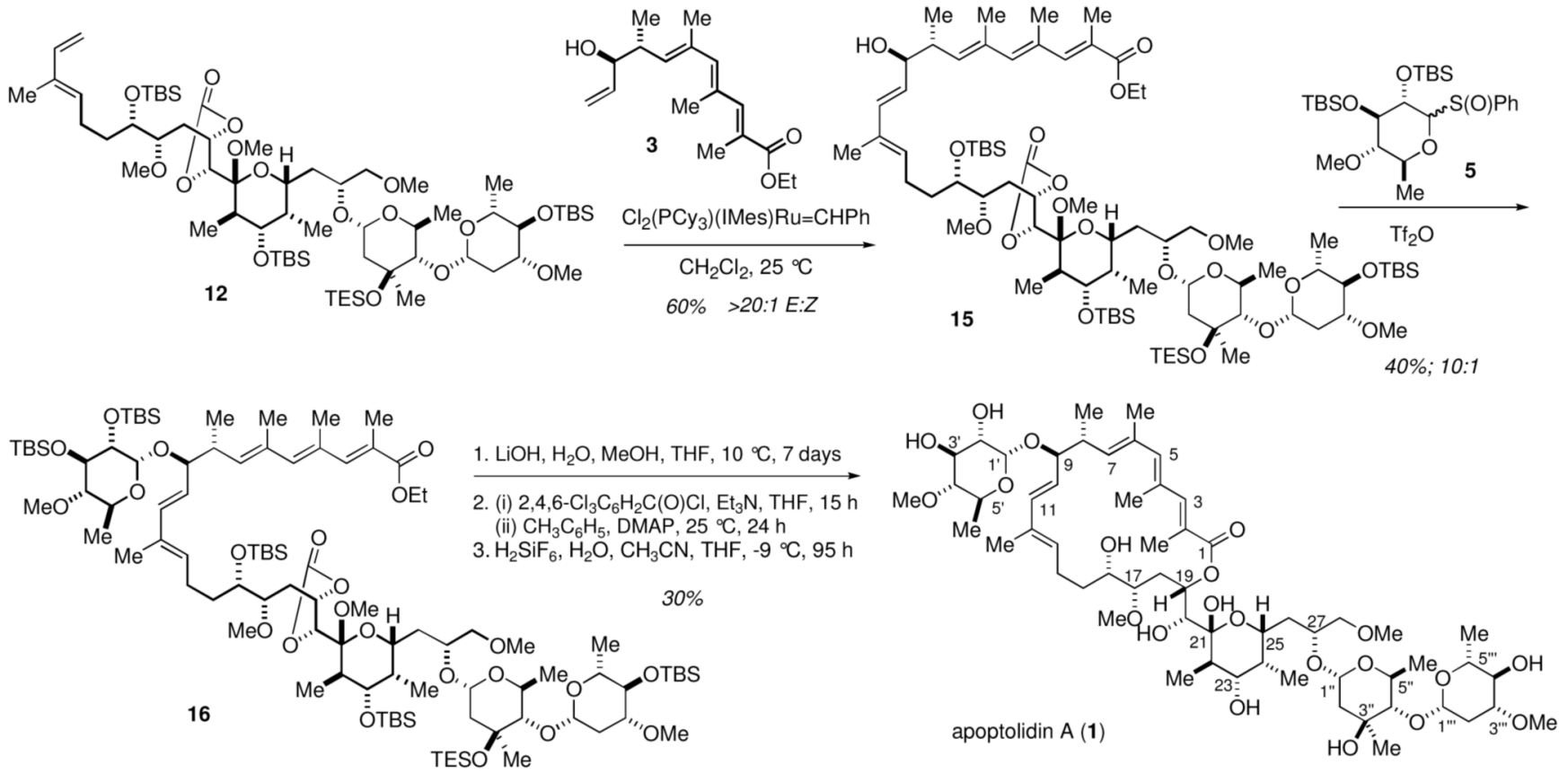

Scheme 5. Synthesis of Apoptolidin A

Org Lett. Author manuscript; available in PMC 2010 February 19. 


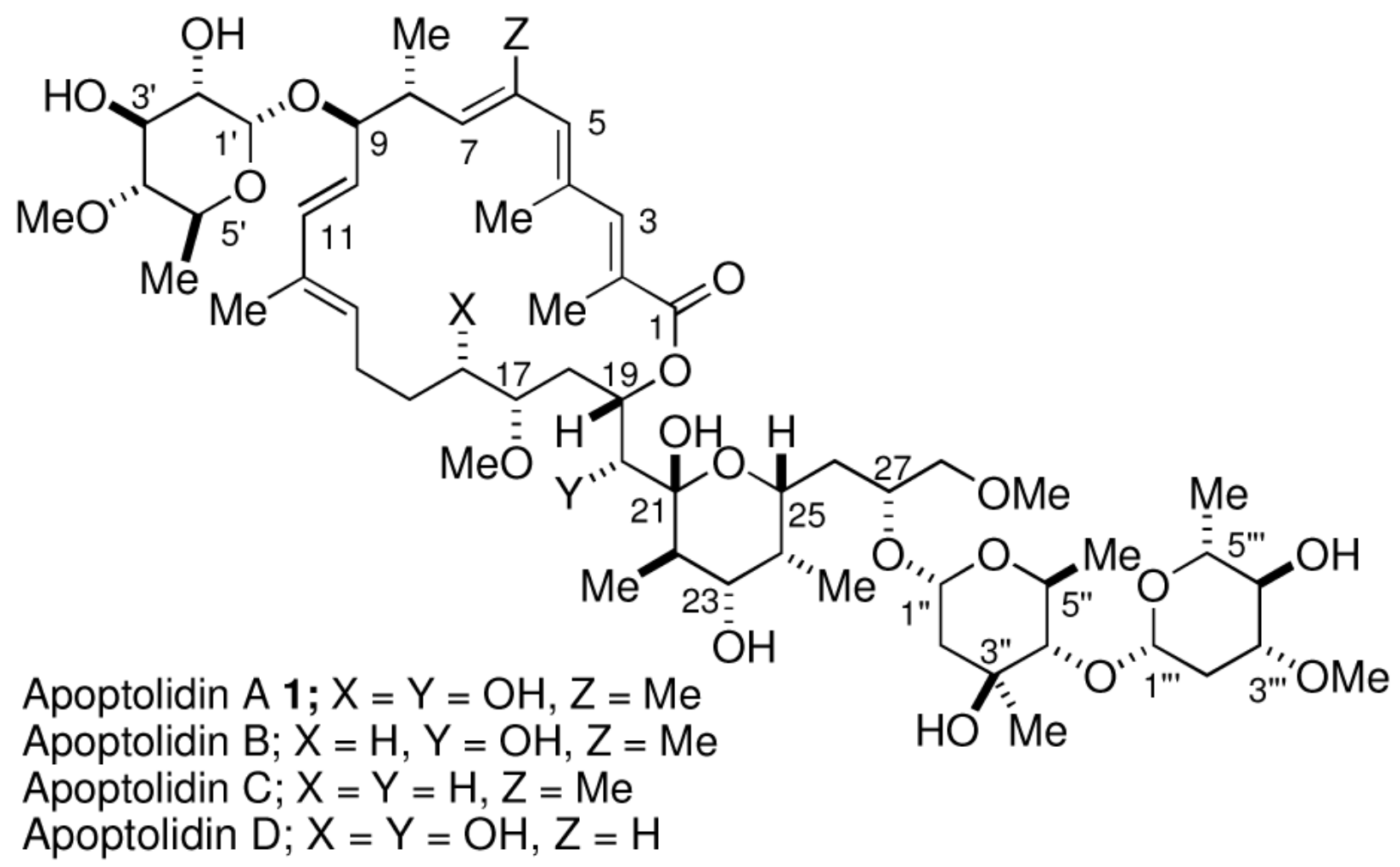

Figure 1.

Structure of the Apoptolidins 